\title{
ANALISIS KEMACETAN LALU LINTAS DI PERSIMPANGAN JL. KAPTEN MULYADI
}

\author{
Muhammad Arifin \\ 1) Fakultas Teknik, Program Studi Teknik Sipil, Universitas Veteran Bangun Nusantara, \\ Sukoharjo, Jl. Letjen Sudjono Humardhani, No.1, Jombor, Sukoharjo; Telp. 0271-593156. \\ Email: ariffin748@gmail.com
}

\begin{abstract}
Abstrak
Jalan Kapten Mulyadi merupakan salah satu ruas jalan yang padat di Kota Surakarta. Kondisi lalu lintas di persimpangan Jl. Kapten Mulyadi sering terjadi kemacetan, penyebab utamanya adalah kinerja lampu lalu lintas yang kurang efektif dan volume lalu lintas yang melewati jalan tersebut melebihi dari pada kapasitas dasar. Faktor lain yaitu karena penyempitan, sumber arus lalu lintas dari 3 ruas jalan (Jl. Mayor Sunaryo, Jl. Demangan, Jl. Kapten Mulyadi) yang masuk ke ruas J1. Kapten Mulyadi. Tujuan dilakukan penelitian ini adalah menganalisa perrmasalahan kemacetan dan volume kendaraan yang melewati Jl. Kapten Mulyadi serta kapasitas ruas Jl. Kapten Mulyadi. Berdasarkan hasil analisa menunjukkan bahwa panjang antrian lengan Selatan (Jl. Kapten Mulyadi) 62,55 m, lengan Timur (Jl. Untung Suropati) 23,30 m, lengan Barat (Jl. Untung Suropati) $15,78 \mathrm{~m}$, dan lengan Utara (Jl. Kapten Mulyadi) 260,25 m dengan waktu siklus total 113 detik dan derajat kejenuhan (DS) tertinggi 1,398. Maka rekomendasi (alternatif I perancangan waktu siklus) dengan waktu siklus 121 detik, derajat kejenuhan (DS) tertinggi 1,320. Alternatif II perancangan waktu siklus dan pelebaran $1 \mathrm{~m}$ untuk masing - masing bahu jalan kanan - kiri, dengan waktu siklus 131 detik dan derajat kejenuhan tertinggi 1,046 .
\end{abstract}

Kata kunci: Kemacetan Lalu Lintas, Siklus Lampu Lalu Lalu Lintas

\begin{abstract}
Jalan Captain Mulyadi is one of the busy roads in the city of Surakarta. Traffic conditions at the junction of Jl. Captain Mulyadi often happens in traffic jams, the main cause of which is the performance of traffic lights that are less effective and the volume of traffic passing through the road exceeds the basic capacity. Another factor is due to the narrowing, the source of traffic flow from 3 roads (Jl. Mayor Sunaryo, Jl. Demangan, Jl. Kapten Mulyadi) that enter the Jl. Captain Mulyadi. The purpose of this research is to analyze traffic jams and the volume of vehicles that pass through Jl. Captain Mulyadi and Jl. Captain Mulyadi. Based on the results of the analysis showed that the length of the South arm queue (Jl. Kapten Mulyadi) $62.55 \mathrm{~m}$, the East arm (Jl. Untung Suropati) $23.30 \mathrm{~m}$, the West arm (Jl. Untung Suropati) $15.78 \mathrm{~m}$, and the North arm ( Jl. Captain Mulyadi) $260.25 \mathrm{~m}$ with a total cycle time of 113 seconds and the highest degree of saturation (DS) of 1.398. Then the recommendation (alternative I design cycle time) with a 121 second cycle time, the highest degree of saturation (DS) of 1,320. Alternative II is the design of the cycle time and widening of $1 \mathrm{~m}$ for each right - left shoulder, with a cycle time of 131 seconds and the highest degree of saturation of 1.046.
\end{abstract}

Keywords: Traffic Congestion, Traffic Light Cycle

\section{PENDAHULUAN}

Kota diartikan sebagai suatu sistem jaringan kehidupan yang ditandai dengan kepadatan penduduk yang tinggi dan diwarnai dengan strata ekonomi yang heterogen dan bercorak materialistis. Sehingga kelangsungan kota harus didukung oleh sarana prasarana yang memadai untuk waktu yang selama mungkin (Bintarto, 1983).

Transportasi merupakan fasilitas pendukung kegiatan manusia, transportasi juga tidak dapat dipisahkan dari aspek - aspek aktivitas manusia tersebut. Transportasi menjadi kebutuhan yang mendasar bagi manusia, tanpa adanya transportasi manusia dapat terisolasi dan tidak dapat melakukan mobilisasi. Manfaat mobilisasi tersebut dapat di lihat dari berbagai aspek sesuai tujuannya, yaitu aspek ekonomi, sosial, politis. Di kota, transportasi berkaitan dengan kebutuhan pekerja untuk mencapai lokasi pekerjaannya, kebutuhan pelajar untuk mencapai sekolah, untuk mengunjungi pusat perbelanjaan, atau bahkan 
untuk ke luar kota. Disamping untuk mengangkut orang, transportasi juga dapat digunakan untuk memindahkan barang dari suatu tempat ke tempat yang lain.

Tingkat pertumbuhan ekonomi yang cukup tinggi telah menarik arus urbanisasi yang tinggi sebab bagi kebanyakan masyarakat hal ini menjanjikan kesempatan kerja yang lebih luas. Hal ini menjadikan tingkat pertumbuhan penduduk dan pekerja yang tinggi di wilayah ini. Tidak meratanya pertumbuhan wilayah secara tidak langsung dapat dikatakan sebagai penyebab dari tingginya urbanisasi.

Dewasa ini sistem transportasi di Indonesia mengalami banyak permasalahan yang paling utama menjadi sorotan publik adalah kemacetan, salah satunya Kota Surakarta. Kota Surakarta berkembang sangat pesat, salah satunya di Jl. Kapten Mulyadi, kawasan ini merupakan jalur penghubung antara wilayah

Surakarta dengan Sukoharjo. Jalan Kapten Mulyadi ini merupakan jalan lokal dan menjadi jalur alternatif bagi kendaraan dari arah Sukoharjo ke Surakarta dan sebaliknya.

Kondisi lalu lintas pada jalur kiri dari arah Surakarta menuju Solo Baru terjadi kemacetan yang sangat parah, terutama pada saat kendaraan berat /kontainer melalui jalur tersebut, penyebab utama yang menyebabkan kemacetan tersebut adalah kinerja lampu lalu lintas yang kurang efektif. Seperti yang terjadi pada Jl. Demangan dan Jl. Mayor Sunaryo terjadi konflik pada persimpangan depan PT. Praja Ghupta, Kelurahan Kedung Lumbu, Kecamatan Pasar Kliwon, hal ini disebabkan oleh jauhnya jarak yang ditempuh kendaraan dari Jl. Demangan dan J1. Mayor Sunaryo menuju Jl. Kapten Mulyadi, tidak sebanding dengan waktu pengosongan (clereance time) yang cepat atau singkat, sehingga terjadi penumpukan di jalur kiri Jl. Kapten Mulyadi dari arah Surakarta.

Kemacetan bertambah parah dengan adanya kendaraan yang ingin belok di pertigaan dari arah utara Jl. Kapten Mulyadi menju Jl. Kyai Gede hal ini menjadikan antrian kendaraan semakin panjang, yang awalnya kendaraan hanya menunggu lampu lalu lintas, namun dengan adanya kendaraan yang ingin berbelok ke Jl. Kyai Gede kendaraan di belakannya harus berhenti, hal ini mengakibatkan antrian kendaraan yang sangat panjang. Faktor lain, kendaraan khusus penumpang (bus) berhenti tidak pada tempatnya yang menyebabkan antrian semakin parah.

Kendaraan yang tertahan oleh tanda lampu merah pada suatu jalan pendekat kemudian mendapat hak jalan, mula - mula kendaraan melakukan percepatan hingga mencapai kecepatan normal ketika laju arus kurang lebih konstan atau pada keadaan yang disebut arus jenuh yaitu mulai berjalan setelah berhenti pada lampu merah.

Dengan menganggap terdapat jumlah kendaraan yang cukup banyak dalam antrian untuk berjalan pada saat lampu hijau (selama waktu lampu hijau lalu lintas sangat jenuh), kendaraan akan terus berjalan keluar pada arus jenuh ini hingga waktu hijau habis. Ada beberapa kendaraan yang akan lewat pada saat lampu kuning, tetapi laju pengeluaran akan turun sampai nol. Selama satu fase, jumlah waktu hijau $(k)$ dan waktu kuning $(\alpha)$, dikurangi waktu hijau efektif $(g)$ disebut sebagai waktu yang hilang (lost time, I), karena ini umumnya tidak terdapat pada fase lain untuk lewatnya kendaraan, dan ditulis sebagai berikut :

$I=k+\alpha-g I$

Bila $b$ merupakan jumlah kendaraan rata - rata yang keluar selama fase jenuh, dengan arus jenuh $s$, maka $g$ (waktu hijau efektif), yaitu :

$g=\frac{b}{s}$

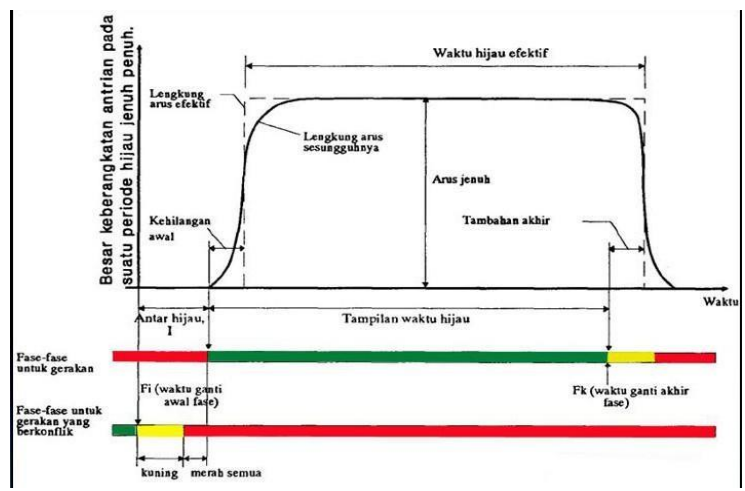

Gambar 1 Model Dasar Arus Jenuh (MKJI, 1997)

Gambar 1 menunjukan Model dasar arus jenuh berdasarkan MKJI 1997. Sinyal pada semua fase yang menunjukkan merah, atau merah/kuning bersama-sama juga merupakan 
unsur dari waktu hilang, karena di persimpangan jalan tidak ada kendaraan yang bergerak. Bila unsur waktu hilang adalah $\mathrm{R}$, maka waktu hilang total per siklus, yaitu :

$L=n l+R=\sum(l-\alpha)+\sum l$

dengan :

$\mathrm{L}=$ Waktu hilang rata - rata per fase

$\mathrm{R}=$ Waktu hilang per siklus, karena all red atau red dan amber pada semua fase

$\mathrm{n}=$ Jumlah fase

$1=$ Periode pergantian hijau

$\alpha \quad=$ Periode kuning

Waktu merah semua diperlukan untuk pengosongan pada setiap akhir fase dan harus memberi kesempatan untuk kendaraan terakhir melewati garis henti pada akhir sinyal (kuning) berangkat dari titik konflik sebelum kedatangan kendaraan yang datang pertama dari fase berikutnya pada titik yang sama.

Panjang waktu kuning pada sinyal lalu lintas perkotaan di Indonesia biasanya adalah sebesar 3 detik.

\section{Kapasitas Simpang dan Derajat Kejenuhan}

Perhitungan kapasitas dapat dibuat dengan pemisahan jalur tiap pendekat, pada satu lengan dapat terdiri dari satu atau lebih pendekat, misal dibagi menjadi dua atau lebih sub pendekat (MKJI, 1997). Hal ini dapat diterapkanapabila gerakan belok kanan mempunyai fase berbeda dari lalu lintas yang lurus atau dapat juga merubah fisik jalan yaitu dengan membagi pendekat dengan pulau lalu lintas (canalization). Kapasitas (C) dari suatu pendekat simpang bersinyal dapat dinyatakan sebagai berikut :

$C=S \times g / c$

dengan :

$\mathrm{C}=$ Kapasitas pendekat (smp/jam)

$\mathrm{S}=$ Arus jenuh (smp/jam hijau)

$\mathrm{g}=$ Waktu hijau (detik)

$\mathrm{c}=$ Waktu siklus

\section{Panjang Antrian}

Menurut MKJI 1997, antrian yang terjadi pada suatu pendekat adalah jumlah rata - rata antrian smp pada awal sinyal hijau $(N Q)$ yang merupakan jumlah smp yang tersisa dari fase hijau sebelumnya (NQ1) dan jumlah smp yang datang selam waktu merah (NQ2) yang persamaannya seperti berikut :

$$
N Q=N Q 1+N Q 2
$$

Panjang antrian (QL) pada suatu pendekat adalah hasil perkalian jumlah rata - rata antran yang pada awal hijau sinyal (NQ) dengan luas rata - rata yang dipergunakan per smp $\left(20 \mathrm{~m}^{2}\right)$ dan pembagian lebar masuk, yang persamaannya dituliskan sebagai berikut :

$Q L=N Q^{M A X} x \frac{20}{W_{\text {Masuk }}}$

\section{Kendaraan Berhenti}

Perhitungan laju henti (NS) untuk masing masing pendekat yang diidentifikasikan sebagai jumlah rata - rata berhenti per smp (termasuk berhenti terulang dalam antrian), dapat dihitung dengan persamaan :

$N S=0,9 \times \frac{N Q}{Q \times C} \times 3600$

\section{Tundaan}

Menurut MKJI 1997, tundaan (D) pada suatu simpang dapat terjadi karena 2 (dua) hal, yaitu

1.Tundaan lalu lintas (DT) yang disebabkan oleh interaksi lalu lintas dengan gerakan lainnya pada suatu simpang.

2.Tundaan geometrik (DG) yang disebabkan oleh perlambatan dengan percepatan saat membelok pada suatu simpang dan atau terhenti karena lampu merah. Tundaan rata rata untuk pendekat $\mathrm{j}$ merupakan (DGj) yang persamaannya dapat dituliskan seperti berikut :

$D=D T+D G$

Tingkat pelayanan pada persimpangan secara lengkap seperti tampak pada Tabel 1 . 
Tabel 1 Tingkat Pelayanan Pada Persimpangan

\begin{tabular}{|c|c|c|}
\hline $\begin{array}{l}\text { Tingkat } \\
\text { Pelayanan }\end{array}$ & Karakteristik - karakteristik & Batas Lingkup V/C \\
\hline $\mathbf{A}$ & $\begin{array}{c}\text { Kondisi arus bebas dengan kecepatan tinggi dan volume lalu lintas rendah. } \\
\text { Pengemudi dapat memilih kecepatan yang diinginkan tanpa hambatan. } \\
\text { Dalam zona arus stabil. }\end{array}$ & $0,00-0,19$ \\
\hline B & $\begin{array}{l}\text { Pengemudi memiliki kebebasan yang cukup untuk memilih kecepatan. } \\
\text { Dalam zona arus stabil. }\end{array}$ & $0,25-0,44$ \\
\hline $\mathbf{C}$ & Pengemudi dibatasi dalam memilih kecepatan.. & $0,45-0,75$ \\
\hline $\mathbf{D}$ & $\begin{array}{c}\text { Mendekati arus tidak stabil dimana hampir seluruh pengemudi di batasi. } \\
\text { Volume pelayanan berkaitan dengan kapasitas yang dapat } \\
\text { ditolerir (diterima) }\end{array}$ & $0,75-0,84$ \\
\hline $\mathbf{E}$ & $\begin{array}{l}\text { Volume lalu lintas mendekati atau berada pada kapasitasnya. Arus adalah } \\
\text { tidak stabil dengan kondisi yang sering berhenti. }\end{array}$ & $0,85-1,0$ \\
\hline $\mathbf{F}$ & $\begin{array}{l}\text { Arus yang dipaksakan atau macet pada kecepatan yang rendah. Antrian } \\
\text { yang panjang dan terjadi hambatan - hambatan yang besar. }\end{array}$ & Lebih dari 1,0 \\
\hline
\end{tabular}

Dalam penelitian ini menganalisa permasalahan penumpukan dan Berapa besar volume serta kapasitas kendaraan yang melewati Kapten Mulyadi, Surakarta. Tujuan dilakukan penelitian ini adalah menganalisa perrmasalahan kemacetan dan volume kendaraan yang melewati Jl. Kapten Mulyadi serta kapasitas ruas $\mathrm{Jl}$.

\section{METODE}

\section{Alat dan bahan}

Alat - alat yang diperlukan untuk melakukan survey agar survey dilapangan dapat berjalan dengan baik, antara lain meliputi :

\section{a. Meteran}

Meteran digunakan untuk menentukan titik awal dari survey sampai titik akhir survey dimana menganalisa kapasitas serta tundaan pada persimpangan dan juga untuk mengukur geometrik jalan, serta panjang antrian.

b. Pengukur Waktu (jam atau stopwatch) Dalam menganalisa tundaan serta kapasitas ruas jalan dilakukan pada jamjam sibuk sehingga didapatkan volume maksimal kendaraan yang melintasi jalan, pada persimpangan tersebut dihitung setiap interval 15 menit, serta menghitung waktu nyala setiap lampu lalu lintas, oleh karena itu perlu menggunakan alat pengukur waktu (jam/stopwatch).

Setelah data dikonversi menjadi satuan mobil penumpang maka berdasarkan teori - teori transportasi maka dilakukan tahapan - tahapan sebagai berikut :

1. Analisis perhitungan kapasitas berdasarkan MKJI 1997

2. Fase sinyal

3. Waktu antar hijau (IG)

4. Waktu hilang (LTI)

5. Waktu merah semua

6. Waktu siklus

7. Waktu hijau $(\mathrm{g})$

8. Waktu siklus yang disesuaikan (c)

Digram alir penelitian secara lengkap seperti tampak pada Gambar 2.

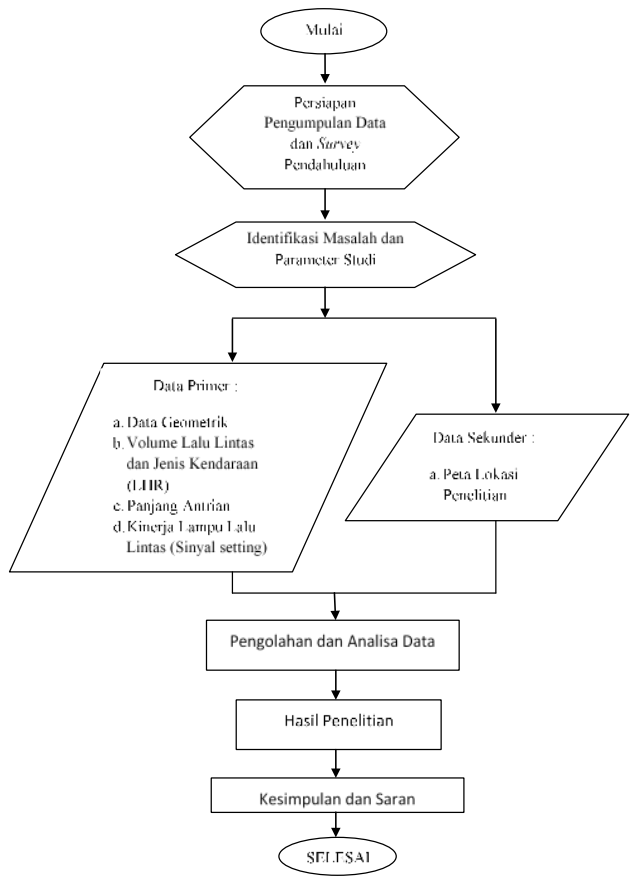

Gambar 2 Diagram Alir Tahap - tahap Penelitian 


\section{HASIL DAN PEMBAHASAN}

Hasil analisa yang mengacu pada MKJI 1997, bahwa pada kondisi eksisting menunjukkan bahwa kinerja simpang depan PT. Praja Ghupta, Kelurahan Kedung Lumbu, Kecamatan Pasar Kliwon, Surakarta, tidak memenuhi persyaratan pada rumus peraturan MKJI 1997. Kapasitas jalan yang terlalu kecil dan tidak sebanding dengan volume arus lalu lintas kendaraan sehingga menyebabkan meningkatnya derajat kejenuhan, menambah panjang antrian dan tundaan. Berdasarkan analisis yang telah dilakukan pada kondisi eksisting nilai derajat kejenuhan (DS > 0,85), guna mengurangi serta meminimalisir nilai derajat kejenuhan, tundaan serta meningkatkan pelayanan maka dibutuhkan beberapa alternatif solusi, antara lain :

a. Alternatif 1 (Perancangan Ulang Waktu Siklus)

b. Alternatif 2 (Penambahan Lebar efektif dan Perancangan Ulang Waktu

\section{Alternatif 1 (Perancangan Ulang Waktu Siklus)}

Pada alternatif 1 dilakukan perancangan ulang waktu siklus, nilai waktu hijau (g) dan waktu siklus yang disesuaikan (c) tidak menggunakan nilai pada kondisi eksisting akan tetapi dengan persamaan berikut : Waktu hijau $(g)=\left(C_{U A}-\right.$ LTI) $x P R$

Waktu siklus yang disesuaikan $(c)=\sum g+L T I$

Waktu hijau (g) lengan utara menggunakan persamaan berikut :

$$
\begin{aligned}
\mathrm{g} & =\left(\mathrm{C}_{\mathrm{UA}}-\mathrm{LTI}\right) \times \mathrm{PR} \\
= & (100-17,886) \times 0,618649535 \\
= & 51 \text { detik }
\end{aligned}
$$

Waktu siklus yang disesuaikan menggunakan persamaan berikut :

$$
\begin{aligned}
\mathrm{c} & =\sum \mathrm{g}+\mathrm{LTI} \\
& =103+17,886 \\
& =121 \operatorname{detik}
\end{aligned}
$$

Dengan persamaan diatas maka diperoleh waktu hijau dan waktu siklus yang disesuaikan dalam tabel di bawah :

\begin{tabular}{|c|c|c|c|c|c|}
\hline \multirow{2}{*}{$\begin{array}{c}\text { Kod } \\
\text { e } \\
\text { Pend } \\
\text { ekat }\end{array}$} & \multirow{2}{*}{$\begin{array}{l}\text { Tipe } \\
\text { Pend } \\
\text { ekat }\end{array}$} & \multicolumn{4}{|c|}{$\begin{array}{l}\text { Waktu } \\
\text { (detik) }\end{array}$} \\
\hline & & $\begin{array}{c}\text { Mera } \\
\mathrm{h}\end{array}$ & $\begin{array}{c}\mathrm{Hija} \\
\mathrm{u}\end{array}$ & $\begin{array}{c}\text { Kuni } \\
\text { ng }\end{array}$ & $\begin{array}{l}\text { All } \\
\text { red }\end{array}$ \\
\hline $\mathbf{U}$ & $\mathrm{P}$ & 67 & 51 & 3 & 3 \\
\hline $\mathbf{S}$ & $\mathrm{P}$ & 86 & 31 & 3 & 3 \\
\hline $\mathbf{T}$ & $\mathrm{O}$ & 94 & 21 & 3 & 3 \\
\hline B & $\mathrm{O}$ & & & & \\
\hline \multicolumn{2}{|c|}{$\begin{array}{l}\text { Waktu } \\
\text { siklus }\end{array}$} & & & 121 & \\
\hline
\end{tabular}

Dengan persamaan diatas maka diperoleh waktu hijau dan waktu siklus yang disesuaikan dalam tabel 2.

Tabel 2 Perancangan Ulang Waktu Siklus dan Waktu Hijau Alternatif 1

Diagram Waktu Siklus Setelah Perencanaan Ulang Alternatif 1 seperti tampak pada Gambar 3.

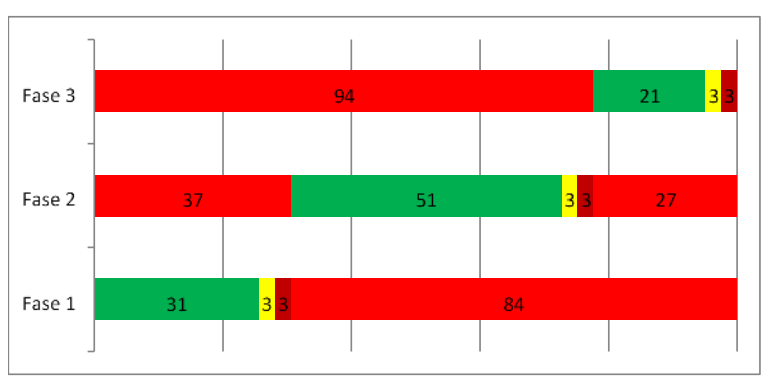

Gambar 3 Diagram Waktu Siklus Setelah Perancangan Ulang Pada Alternatif 1

Nilai arus jenuh (S) setelah penambahan waktu hijau disajiakan dalam tabel 3.

Tabel 3 Arus Jenuh Setelah Perancangan Waktu Siklus Alternatif 1

\begin{tabular}{ccccc}
\hline So & $\begin{array}{c}\text { Selata } \\
\mathbf{n}\end{array}$ & Timur & Barat & Utara \\
\cline { 2 - 5 } $\begin{array}{c}\text { (smp/ja } \\
\mathbf{m})\end{array}$ & 2700 & 1948 & 2274 & 2700 \\
\hline FCS & 1,05 & 1,05 & 1,05 & 1,05 \\
\hline FSF & 0,95 & 0,98 & 0,98 & 0,95 \\
\hline FG & 1,0 & 1,0 & 1,0 & 1,0 \\
FP & 1,0 & 1,0 & 1,0 & 1,0 \\
\hline FRT & 1,0294 & 1,0 & 1,0 & 1,0167 \\
& 01268 & & & 78788 \\
\hline FLT & 1,0240 & 1,0 & 1,0 & 1,0268 \\
\hline $\mathbf{S}$ & 2 & & & 37296 \\
\hline $\begin{array}{c}\text { (smp/ja } \\
\text { m) }\end{array}$ & 2839,0 & 2004,492 & 2339,9 & 2811,9 \\
\hline
\end{tabular}


Besarnya nilai kapasitas (C) tergantung pada arus jenuh dan rasio waktu hijau pada masing - masing pendekat. Pada alternatif 1 dilakukan analisis ulang dengan menggunakan waktu siklus dan waktu hijau baru sehingga di dapatkan hasil kapasitas seperti pada tabel 4.

Tabel 4 Kapasitas Setelah Perancangan Ulang Waktu Siklus Alternatif 1

\begin{tabular}{|c|c|c|c|c|c|c|}
\hline $\begin{array}{r}\text { Period e } \\
\text { Waktu }\end{array}$ & $\begin{array}{c}\text { Kode } \\
\text { Pendeka } \\
\mathbf{t}\end{array}$ & $\begin{array}{l}\text { Tipe } \\
\text { Pende } \\
\text { kat }\end{array}$ & $\begin{array}{l}\text { Arus Jenuh } \\
\text { (S) (smp/jam) }\end{array}$ & $\begin{array}{c}\text { Waktu } \\
\text { Hijau (g) } \\
\text { (detik) }\end{array}$ & $\begin{array}{l}\text { Waktu Siklus } \\
\text { yang } \\
\text { disesuaikan } \\
\text { (c) (detik) }\end{array}$ & $\begin{array}{c}\text { Kapasitas (C) } \\
\text { (smp/jam) }\end{array}$ \\
\hline \multirow{4}{*}{$\begin{array}{c}07.00 \text { - } \\
08.00 \\
\text { WIB }\end{array}$} & $\mathrm{U}$ & $\mathrm{P}$ & 2811,931781 & 51 & \multirow{4}{*}{121} & 1185,194387 \\
\hline & $\mathrm{S}$ & $\mathrm{P}$ & 2839,028853 & 31 & & 727,3544995 \\
\hline & $\mathrm{T}$ & $\mathrm{O}$ & 2339,964 & \multirow{2}{*}{21} & & 406,1094545 \\
\hline & B & $\mathrm{O}$ & 2004,492 & & & 347,8870413 \\
\hline
\end{tabular}

Nilai derajat kejenuhan (DS) dengan perancangan ulang waktu siklus di dapatkan hasil seperti tabel 5 .

Tabel 5 Derajat Kejenuhan Setelah Perancangan Ulang Waktu Siklus Alternatif 1

\begin{tabular}{|c|c|c|c|c|c|}
\hline $\begin{array}{l}\text { Peri } \\
\text { ode } \\
\text { Wa } \\
\text { ktu }\end{array}$ & $\begin{array}{l}\text { Kode } \\
\text { Pend } \\
\text { ekat }\end{array}$ & $\begin{array}{l}\text { Tipe } \\
\text { Pend } \\
\text { ekat }\end{array}$ & $\begin{array}{c}\text { Ar } \\
\text { us } \\
\text { Lal } \\
\mathbf{u} \\
\text { Lin } \\
\text { tas } \\
\text { (Q) }\end{array}$ & $\begin{array}{c}\text { Kapasit } \\
\text { as (C) } \\
(\text { smp/ja } \\
\text { m) }\end{array}$ & $\begin{array}{c}\text { Derajat } \\
\text { Kejenu } \\
\text { han } \\
\text { (DS) }\end{array}$ \\
\hline \multirow{4}{*}{$\begin{array}{c}\text { 07.0 } \\
0- \\
08.0 \\
\text { 0 } \\
\text { WI } \\
\text { B }\end{array}$} & $\mathrm{U}$ & $\mathrm{P}$ & $\begin{array}{c}156 \\
5\end{array}$ & $\begin{array}{l}1185,1 \\
94387\end{array}$ & $\begin{array}{l}1,3204 \\
58498\end{array}$ \\
\hline & $\mathrm{S}$ & $P$ & 974 & $\begin{array}{l}727,35 \\
44995\end{array}$ & $\begin{array}{l}1,0139 \\
77406\end{array}$ \\
\hline & $\mathrm{T}$ & $\mathrm{O}$ & 237 & $\begin{array}{l}406,10 \\
94545\end{array}$ & $\begin{array}{l}0,5835 \\
86512\end{array}$ \\
\hline & B & $\mathrm{O}$ & 155 & $\begin{array}{l}347,88 \\
70413\end{array}$ & $\begin{array}{l}0,4455 \\
46921\end{array}$ \\
\hline
\end{tabular}

Pada alternatif 2 dilakukan penamban lebar efektif sebesar 1 meter untuk bahu kanan dan kiri untuk Jl. Kapten Mulyadi (Selatan - Utara ) serta dilakukan perancangan ulang waktu siklus (c) dengan menggunakan persamaan yang sama seperti alternatif 1 . Geometrik simpang setelah penambahan lebar seperti tampak pada Tabel 6.

Dari perhitungan alternatif 2 perancangan ulang waktu siklus dan penambahan lebar efektif simpang empat Jl. Kapten Mulyadi dihasilkan waktu siklus baru seperti tampak pada tabel 7 .
Tabel 6 Geometrik Simpang Empat Jl. Kapten Mulyadi Setelah dilakukan penambahan lebar efektif sebesar $1 \mathrm{~m}$.

\begin{tabular}{|c|c|c|c|c|}
\hline \multirow{2}{*}{$\begin{array}{l}\text { Nama } \\
\text { Jalan }\end{array}$} & \multicolumn{4}{|c|}{ Pendekat (m) } \\
\hline & $\begin{array}{c}\text { Lebar } \\
\text { Pendekat }\end{array}$ & $\begin{array}{c}\text { Lebar } \\
\text { Masuk }\end{array}$ & $\begin{array}{l}\text { Lebar } \\
\text { Keluar }\end{array}$ & $\begin{array}{c}\text { Lebar } \\
\text { LTOR }\end{array}$ \\
\hline $\begin{array}{c}\text { Jl. } \\
\text { Kapten } \\
\text { Mulyadi } \\
\text { (Selatan) }\end{array}$ & 5,5 & 5,5 & 5,5 & - \\
\hline $\begin{array}{c}\text { Jl. } \\
\text { Untung } \\
\text { Suropati } \\
\text { (Timur) }\end{array}$ & 3 & 3 & 3 & - \\
\hline $\begin{array}{c}\text { Jl. } \\
\text { Kapten } \\
\text { Mulyadi } \\
\text { (Utara) }\end{array}$ & 5,5 & 5,5 & 5,5 & - \\
\hline $\begin{array}{c}\text { Jl. } \\
\text { Untung } \\
\text { Suropati } \\
\text { (Barat) }\end{array}$ & 3 & 3 & 3 & - \\
\hline
\end{tabular}

Diagram Waktu Siklus Setelah Penambahan Lebar Efektif dan Perancangan Ulang Waktu Siklus Simpang Bersinyal Jl. Kapten Mulyadi Alternatif 2 seperti ditampilkan pada Gambar 4.

Tabel 7 Waktu Siklus Alternatif 2

\begin{tabular}{|c|c|c|c|c|c|}
\hline \multirow{2}{*}{$\begin{array}{c}\text { Kode } \\
\text { Pendeka } \\
\mathbf{t}\end{array}$} & \multirow{2}{*}{$\begin{array}{c}\text { Tipe } \\
\text { Pendeka } \\
\text { t }\end{array}$} & & \multicolumn{3}{|c|}{$\begin{array}{l}\text { Waktu } \\
\text { (detik) }\end{array}$} \\
\hline & & $\begin{array}{c}\text { Mera } \\
\mathrm{h}\end{array}$ & $\begin{array}{c}\text { Hija } \\
\mathrm{u}\end{array}$ & $\begin{array}{c}\text { Kunin } \\
\mathrm{g}\end{array}$ & $\begin{array}{l}\text { All } \\
r e \\
d\end{array}$ \\
\hline $\mathbf{U}$ & $\mathrm{P}$ & 70 & 57 & 3 & 3 \\
\hline $\mathbf{S}$ & $\mathrm{P}$ & 92 & 35 & 3 & 3 \\
\hline $\mathbf{T}$ & $\mathrm{O}$ & \multirow{2}{*}{104} & \multirow{2}{*}{21} & \multirow{2}{*}{3} & \multirow{2}{*}{3} \\
\hline B & $\mathrm{O}$ & & & & \\
\hline
\end{tabular}




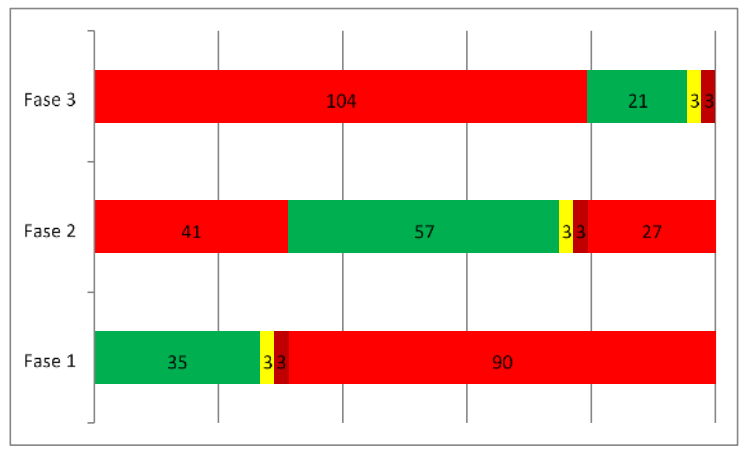

Gambar 4 Diagram Waktu Siklus Alternatif 2

Nilai arus jenuh (S) setelah dilakukan penambahan lebar efektif alternatif 2 didapat hasil perhitungan pada tabel 8 .
Tabel 8 Arus Jenuh (S) Setelah Penambahan Lebar Efektif $(1 \mathrm{~m})$

\begin{tabular}{ccccc}
\hline $\begin{array}{c}\text { So } \\
(\mathbf{s m p} / \mathbf{j a} \\
\mathbf{m})\end{array}$ & Selatan & Timur & Barat & Utara \\
\cline { 2 - 5 } FCS & 3300 & 1948 & 2274 & 3300 \\
\hline $\mathbf{F S F}$ & 0,95 & 0,98 & 0,98 & 0,95 \\
\hline $\mathbf{F G}$ & 1,0 & 1,0 & 1,0 & 1,0 \\
\hline $\mathbf{F P}$ & 1,0 & 1,0 & 1,0 & 1,0 \\
\hline FRT & $\begin{array}{c}1,0294012 \\
68\end{array}$ & 1,0 & 1,0 & $\begin{array}{c}1,0167787 \\
88\end{array}$ \\
\hline $\mathbf{F L T}$ & 1,02402 & 1,0 & 1,0 & $\begin{array}{c}1,0268372 \\
96\end{array}$ \\
\hline $\mathbf{S}$ & 3469,9241 & 2004,4 & 2339,9 & $\begin{array}{c}3436,8055 \\
11\end{array}$ \\
$\begin{array}{c}\mathbf{s m p} / \mathbf{j a} \\
\mathbf{m})\end{array}$ & 54 & 92 & 46 &
\end{tabular}

Pada alternatif 2 dilakukan analisis ulang dengan menggunakan waktu siklus dan waktu hijau baru sehingga di dapatkan hasil kapasitas seperti pada Tabel 9 .

Tabel 9 Kapasitas (C) Setelah Penambahan Lebar Efektif

\begin{tabular}{|c|c|c|c|c|c|c|}
\hline $\begin{array}{l}\text { Periode } \\
\text { Waktu }\end{array}$ & $\begin{array}{c}\text { Kode } \\
\text { Pendekat }\end{array}$ & $\begin{array}{c}\text { Tipe } \\
\text { Pende } \\
\text { kat }\end{array}$ & $\begin{array}{c}\text { Arus Jenuh } \\
\text { (S) } \\
\text { (smp/jam) }\end{array}$ & $\begin{array}{c}\text { Waktu } \\
\text { Hijau (g) } \\
\text { (detik) }\end{array}$ & $\begin{array}{l}\text { Waktu } \\
\text { Siklus } \\
\text { (c) } \\
\text { (detik) }\end{array}$ & $\begin{array}{c}\text { Kapasitas } \\
\text { (C) } \\
\text { (smp/jam) }\end{array}$ \\
\hline \multirow{4}{*}{$\begin{array}{c}07.00 \text { - } \\
\text { 08.00 WIB }\end{array}$} & $\mathrm{U}$ & $\mathrm{P}$ & 3436,805511 & 57 & \multirow{4}{*}{131} & 1495,403924 \\
\hline & S & $\mathrm{P}$ & 3469,924154 & 35 & & 927,0789723 \\
\hline & $\mathrm{T}$ & $\mathrm{O}$ & 2004,492 & \multirow{2}{*}{21} & & 321,3307786 \\
\hline & B & $\mathrm{O}$ & 2339,946 & & & 375,1058473 \\
\hline
\end{tabular}

Nilai derajat kejenuhan (DS) setelah dilakukan penambahan lebar efektif serta perancangan ulang waktu siklus sepeti pada tabel 10 .

Berdasarkan perhitungan alternatif 2 dengan penambahan lebar efektif pendekat utara dan selatan sebesar $1 \mathrm{~m}$ untuk masing - masing bahu jalan serta perancangan ulang waktu siklus, didapatkan nilai waktu siklus 131 detik. Nyala lampu hijau fase 1 lengan selatan - 35 detik, fase 2 lengan timur dan barat -21 detik, dan fase 3 lengan utara 57 detik. Alternatif 2 didapatkan nilai DS untuk lengan utara lebih kecil dari alternatif 1 dan kondisi eksisting, lengan selatan lebih kecil dari kondisi eksisting.

Hasil perhitungan alternatif 1, 2 dan kondisi eksisting dirangkum dalam tabel 11.
Tabel 10 Derajat Kejenuhan (DS) Setelah Penambahan Lebar Efektif dan Perancangan Ulang Waktu Siklus

\begin{tabular}{|c|c|c|c|c|c|}
\hline $\begin{array}{c}\text { Peri } \\
\text { ode } \\
\text { Wak } \\
\text { tu }\end{array}$ & $\begin{array}{c}\text { Kode } \\
\text { Pende } \\
\text { kat }\end{array}$ & $\begin{array}{c}\text { Tipe } \\
\text { Pende } \\
\text { kat }\end{array}$ & $\begin{array}{c}\text { Aru } \\
\text { s } \\
\text { Lal } \\
\text { u } \\
\text { Lint } \\
\text { as } \\
\text { (Q) }\end{array}$ & $\begin{array}{c}\text { Kapasit } \\
\text { as (C) } \\
\text { (smp/ja } \\
\text { m) }\end{array}$ & $\begin{array}{c}\text { Derajat } \\
\text { Kejenu } \\
\text { han } \\
\text { (DS) }\end{array}$ \\
\hline \multirow{4}{*}{$\begin{array}{c}07.0 \\
0- \\
08.0 \\
0 \\
\text { WI } \\
\text { B }\end{array}$} & $\mathrm{U}$ & $\mathrm{P}$ & $\begin{array}{c}156 \\
5\end{array}$ & $\begin{array}{c}1495,40 \\
3924\end{array}$ & $\begin{array}{l}1,04653 \\
9985\end{array}$ \\
\hline & $\mathrm{S}$ & $\mathrm{P}$ & 974 & $\begin{array}{c}927,078 \\
9723\end{array}$ & $\begin{array}{l}1,05061 \\
1684\end{array}$ \\
\hline & $\mathrm{T}$ & $\mathrm{O}$ & 237 & $\begin{array}{c}321,330 \\
7786\end{array}$ & $\begin{array}{l}0,73755 \\
7731\end{array}$ \\
\hline & B & $\mathrm{O}$ & 155 & $\begin{array}{c}375,105 \\
8473\end{array}$ & $\begin{array}{l}0,41321 \\
6699\end{array}$ \\
\hline
\end{tabular}


Tabel 11 Rangkuman Perhitungan Alternatif 1, 2 dan Kondisi Eksisting

\begin{tabular}{cccccc}
\hline No & Analisis & Kode Pendekat & Q & C & DS \\
\hline \multirow{4}{*}{1} & \multirow{3}{*}{ Kondisi Eksisting } & U & 1565 & 1119,795842 & 1,398570152 \\
& & S & 974 & 829,0969217 & 1,174772182 \\
& & T & 237 & 434,8605664 & 0,54500228 \\
& & B & 155 & 372,5162124 & 0,416089273 \\
\hline \multirow{2}{*}{2} & \multirow{2}{*}{ Alternatif 1 } & U & 1565 & 1249,398309 & 1,320458498 \\
& & S & 974 & 768,4589377 & 1,013977406 \\
& & $\mathrm{~T}$ & 237 & 369,468 & 0,583586512 \\
& & $\mathrm{~B}$ & 155 & 316,4987368 & 0,445546921 \\
\hline \multirow{3}{*}{3} & \multirow{2}{*}{ Alternatif 2 } & $\mathrm{U}$ & 1565 & 1535,593952 & 1,019149625 \\
& & $\mathrm{~S}$ & 974 & 959,7662552 & 1,014830428 \\
& & $\mathrm{~T}$ & 237 & 298,5413617 & 0,793859848 \\
& & $\mathrm{~B}$ & 155 & 348,5025957 & 0,444759958 \\
\hline
\end{tabular}

Berdasarkan pembahasan di atas dengan 2 alternatif maka dapat dibandingkan antara alternatif 1 yaitu dengan perancangan ulang waktu siklus menjadi 121 detik, serta alternatif 2 dengan penambahan lebar efektif untuk bahu jalan ruas Jl. Kapten Mulyadi sebesar 1 meter dan perancangan ulang waktu siklus menjadi 131 detik dengan rincian sebagai berikut :

Alternatif 1 (Perancangan Ulang Waktu Siklus)

- Jl. Kapten Mulyadi (Selatan)

Merah : 84 detik

Hijau : 31 detik

Kuning : 3 detik

- Jl. Untung Suropati (Timur)

Merah : 94 detik

Hijau : 21 detik

Kuning : 3 detik

- Jl. Untung Suropati (Barat)

Merah : $94 \mathrm{dtik}$

Hijau : 21 detik

Kuning : 3 detik

- Jl. Kapten Mulyadi (Utara)

Merah : 64 detik

Hijau : 51 detik

Kuning : 3 detik

Dari alternatif 1 (perancangan ulang waktu siklus) setidaknya menurunkan derajat kejenuhan Utara $=-0,07811654$, Selatan $=-0,160794776$, Timur $=+$

0,038584232 , Barat $=+0,029457648$

Alternatif 2 (Penambahan lebar efektif bahu Jl. Kapten Mulyadi sebesar $1 \mathrm{~m}$ dan perancangan ulang waktu siklus)

- Jl. Kapten Mulyadi (Selatan)

Merah : 90 detik
Hijau : 35 detik

Kuning : 3 detik

- Jl. Untung Suropati (Timur)

Merah : 104 detik

Hijau : 21 detik

Kuning : 3 detik

- Jl. Untung Suropati (Barat)

Merah : 104 dtik

Hijau : 21 detik

Kuning : 3 detik

- Jl. Kapten Mulyadi (Utara)

Merah : 68 detik

Hijau : 57 detik

Kuning : 3 detik

Dari alternatif 2 (Penambahan lebar efektif bahu Jl. Kapten Mulyadi sebesar $1 \mathrm{~m}$ dan perancangan ulang waktu siklus) menurunkan angka derajat kejenuhan sebesar, Utara = 0,352030167 , Timur $=+0,192555451$, Barat $=$ $+0,002872574$, Selatan $=-0,124160498$

\section{KESIMPULAN}

Hasil analisis kemacetan yang terjadi pada persimpangan Jl. Kapten Mulyadi tepatnya depan PT. Praja Ghupta, Kelurahan Kedung Lumbu, Kecamatan Pasar Kliwon, Surakarta disebabkan oleh kurang efektifnya nyala lampu hijau serta volume kendaraan yang melebihi dari kapasitas jalan dari permasalahan di atas menyebabkan antrian kendaraan yang sangat panjang yaitu

Jl. Kapten Mulyadi (Selatan) $=62,55 \mathrm{~m}$,

Jl. Untung Suropati (Timur) $=23,30 \mathrm{~m}$,

Jl. Untung Suropati $($ Barat $)=15,78 \mathrm{~m}$, dan

Jl. Kapten Mulyadi $($ Utara $)=260,25 \mathrm{~m}$. 
Penumpukan kendaraan dan antrian panjang pada kondisi lalu lintas jam puncak pada persimpangan Jl. Kapten Mulyadi untuk masing-masing pendekat menunjukkan nilai DS > 0,8 smp/jam, dan hasil tundaan simpang rata-rata persimpangan Jl. Kapten Mulyadi diperoleh 45,73447 det/smp ini menunjukkan bahwa persimpangan tersebut jenuh dan dalam tingkat pelayanan $\mathrm{F}$, arus tidak stabil dan sering berhenti serta antrian yang panjang.

Berdasarkan analisis diatas dengan 2 alternatif maka dapat dibandingkan antara alternatif 1 yaitu dengan perancangan ulang waktu siklus menjadi 121 detik, serta alternatif 2 dengan penambahan lebar efektif untuk bahu jalan ruas Jl. Kapten Mulyadi sebesar 1 meter dan perancangan ulang waktu siklus menjadi 131 detik.

Dari alternatif 1 (perancangan ulang waktu siklus) setidaknya menurunkan derajat kejenuhan

Utara $=-0,07811654$,

Selatan $=-0,160794776$,

Timur $=+0,038584232$,
Barat $=+0,029457648$

Dari alternatif 2 (Penambahan lebar efektif bahu Jl. Kapten Mulyadi sebesar $1 \mathrm{~m}$ dan perancangan ulang waktu siklus) menurunkan angka derajat kejenuhan sebesar,

Utara $=-0,352030167$,

Timur $=+0,192555451$,

Barat $=+0,002872574$,

Selatan $=-0,124160498$

\section{DAFTAR PUSTAKA}

Ahsan, N. 2015. Simpang Ber-Apill.

http://tingkatkeselamatanjalan.blogspot.com/2 015/simpang-

berhttp://tingkatkeselamatanjalan.blogspot.co m/2015/simpang-ber-

apill 17.html?m=1 apill 17.html?m=1 (diakses pada tanggal 3 November 2018).

Bina Marga. 1997. Manual Kapasitas Jalan Indonesia. Jakarta. Direktorat Jendral Bina Marga. 